\title{
RT-PCR Analysis and Stress Response Capacity of Transgenic gshI-Poplar Clones (Populus $\times$ canescens) in Response to Paraquat Exposure
}

András Bittsánszky ${ }^{\mathrm{a}}$, Gábor Gyulai ${ }^{\mathrm{a}, *}$, Mervyn Humphreys ${ }^{\mathrm{b}}$, Gábor Gullner ${ }^{\mathrm{d}}$,

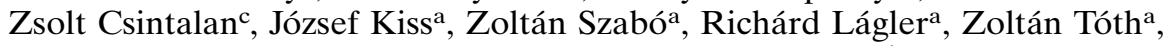
Heinz Rennenberge ${ }^{\mathrm{e}}$ László Heszkya ${ }^{\mathrm{a}}$, and Tamás Kómíves ${ }^{\mathrm{d}}$

a St. Stephanus University, HAS-SIU RG and Department of Genetics and PB, Gödöllő, 2103, Hungary. E-mail: gyulai.gabor@mkk.szie.hu

b IGER, Plas Gogerddan, Aberystwyth, SY23 3EB, United Kingdom

c St. Stephanus University, Department of Botany, Gödöllő, 2103, Hungary

d Plant Protection Institute, Hungarian Academy of Sciences, Budapest, 1525, Hungary

e Albert-Ludwigs-Universität, Institut für Forstbotanik und Baumphysiologie,

D-79085 Freiburg, Germany

* Author for correspondence and reprint requests

Z. Naturforsch. 61 c, 699-703 (2006); received December 20, 2005

Stress response capacity $\left(\mathrm{Fv} / \mathrm{Fm}\right.$ at $690 \mathrm{~nm}$ and F690/F735 at $\left.\mathrm{F}_{\max }\right)$ of untransformed hybrid poplar, Populus $\times$ canescens $(P$. tremula $\times P$. alba), and two transgenic lines overexpressing $\gamma$-ECS ( $\gamma$-glutamylcysteine synthetase) either in the cytosol (cyt-ECS) or in the chloroplast (chl-ECS) was studied in response to the herbicide paraquat $\left(4.0 \times 10^{-9}\right.$ to $4.0 \times 10^{-6}$ M) for 21 days. Significant differences at sublethal $\left(4.0 \times 10^{-7} \mathrm{M}\right)$ and bleaching $\left(4.0 \times 10^{-6}\right.$ M) concentrations of paraquat were observed with about a two-fold and eight-fold decrease in the photosynthetic activity $\left(\mathrm{Fv} / \mathrm{Fm}\right.$ at $690 \mathrm{~nm}$ and F690/F735 at $\left.\mathrm{F}_{\max }\right)$, respectively. None of the gsh I transgenic lines (cyt-ECS, chl-ECS) with elevated GSH content exhibited significant tolerance to paraquat.

Semiquantitative RT-PCR of the cyt-ECS clone was used for gene expression analysis of the nuclear encoded $r b c S$ gene and the stress responsive gst gene. Expression of the constitutively expressed $26 \operatorname{Sr} R N A$ ribosomal gene was probed as a control for all RT-PCR reactions. The relative intensities of gene expressions normalized to the level of $26 \operatorname{SrRNA}$ intensity showed a $50 \%$ decrease in the nuclear encoded $r b c S$ expression and a $120 \%$ increase in the stress responsive gst gene expression of the paraquat treated $\left(4.0 \times 10^{-7} \mathrm{M}\right)$ samples of the transgenic poplar line (cyt-ECS).

Key words: cyt-ECS (ggs11), chl-ECS (lgl6), Paraquat Stress, Populus $\times$ canescens 